\title{
Nutritional Evaluation of Glyricidia Leaf Protein \\ Concentrate as Feed Component in Rabbit's \\ Concentrate Diet
}

\author{
Muyiwa Hilarious Ogunsipe \\ Animal Production Unit, Department of Agricultural Science \\ Adeyemi College of Education, Ondo, Ondo State, Nigeria
}

Tel: 234-803-528-4422Ｅ-mail: moogunsipe2009@yahoo.com

Received: July 3, 2012 Accepted: August 7, 2012 Published: June 1, 2013

doi:10.5296/jfs.v2i1.2038ＵRL: http://dx.doi.org/10.5296/jfs.v2i1.2038

\begin{abstract}
Thirty five weaned rabbits aged 5 to 6 weeks with mean weight $487.00 \mathrm{~g}$ were randomly allocated to five dietary treatment groups (seven animals per group) in a completely randomized design at $0,5,10,15$ and 20\% representing $0,1.31,2.62,3.93$ and 5.24\%, respectively of the gross feed composition. Prior to the feeding trial, the glyricidia leaf protein concentrate (GLPC) was analyzed for the proximate composition, mineral contents, amino acid profile and the anti-nutritional components. The crude protein content of GLPC $\left(420 \mathrm{gkg}^{-1}\right)$ found in this study is similar to the conventional plant protein sources used in animal feed formulation. The crude fibre ranged from 10.13-12.33\%, and this falls within the dietary crude fibre required for growing rabbits. GLPC showed appreciable quantity of minerals, amino acid and low level of anti-nutrients. Dietary inclusion of GLPC had no dire consequence on the carcass cuts, organ weights, hematological profile and serum biochemical of weaned rabbits. Judging from the result, it can therefore be concluded that GLPC contained appreciable level of nutrients that can support rabbit production in this part of the world where glyricidia plants abound.
\end{abstract}

Keywords: Chemical Composition, Hematology, Leaf Protein Concentrate, Serum, Weight, Organ 


\section{Introduction}

Nigeria and other developing countries are currently experiencing low protein consumption of animal origin. This is largely due to the inefficiency of the livestock sector to supply animal protein at affordable cost to an average Nigerian, particularly the low income resource earners. The low level of animal protein supply with concomitant decrease in animal protein intake is due partly, to reduced animal production, imbalanced feed nutrient, high cost of concentrate feed and long generation interval of the traditional livestock, such as cattle, sheep, goat, and poultry. To therefore increase animal protein production, it is imperative to look inwards by sourcing for some unconventional feed resources that are of no economic value to humans to replace the ever expensive and competitive orthodox feed resources. It is also vital to improve the production of mini-livestock with short generation interval and high protein turn over rate.

The suggest animal apart from poultry is rabbit, being a highly prolific livestock with rapid turn over rate, and with low cost of production. Rabbit meat is noted to be a very good source of high quality protein, low fat content, low saturated stearic and oleic acids, low cholesterol content and high polyunsaturated linolenic and linoleic acids (Njidda and Hambagda, 2007; Ghosh and Mandal, 2008). The most limiting factor to livestock production is observed to be the feed cost, particularly concentrate feeds, which account for about $60-70 \%$ of the total production cost (Agbede et al., 2008; Agbede and Agbede, 2009; Ogunsipe et al., 2011). Among the protein supplement that are expensive ingredients in livestock feed formulation are fish meal, soybean meal and groundnut cake. Considering the high cost of these protein supplements, attention is now shifted toward the use of agricultural by-products and wastes, unutilized tropical legume plants, and leaves as well as the plant leaf protein concentrates of some tropical browse legumes. (Aletor and Omodara, 1994; Agbede, 2003; Agbede and Aletor, 2004; Adeyemi et al., 2010; Okonkwo et al., 2010; Njidda and Isidahomen, 2011). Some plant protein concentrates are noted to be high in nutrients, notably protein with high amino acid profile comparable to the orthodox plant protein sources, such as soybean meal and groundnut cake. (Fasuyi, 2005; Agbede, 2006; Agbede et al., 2008; Amata and Bratte, 2008).

Research had shown that most legumes grown in West African countries contain leaf protein concentrates ranging between $351-549 \mathrm{gkg}^{-1}$ crude protein content (Aletor and Omodara, 1994; Aletor et al., 2002; Agbede and Aletor, 2004; Agbede et al., 2008). Agbede and Aletor (2005) and Agbede (2006) reported the crude protein values of the leaf protein concentrates of Mucuna pruriens, (L.), Leucaena leucocephala (Lam.) and Glyricidia sepium (Jacq.) to be between 352.0, and $430.0 \mathrm{gkg}^{-1}$. The chemical composition of some leaf protein concentrates show their promising use as possible protein supplement in feeds (Aletor et al., 2002). This study was therefore conceived with a view to exploit the nutritive potential of glyricidia leaf protein concentrates, using rabbit as the test animal.

\section{Materials and Methods}

\section{Location}

The study was carried out between August 2011 to November 2011 at the Adeyemi College of Education Teaching and Research Farm, Ondo, Ondo State, Nigeria. Ondo is located 


\section{Macrothink

between $07^{0} 05^{1} \mathrm{~N}, 04^{0} 55^{1} \mathrm{E}$ with annual rainfall of between $1800-3600 \mathrm{~mm}$, $54-91 \%$ relative humidity and mean daily temperature range of $22-35^{\circ} \mathrm{C}$ throughout the year.

\section{Test Ingredient and Experimental Diets.}

\section{Processing Leaf Protein Concentrate (Test Ingredient)}

The basic technology for separating the leaf protein from the fibrous part of the leaf has long been established, but a technology for large scale production was not developed until the 1970s (Oke, 1973). In preparing leaf protein concentrate from Glyricidia, fresh leaves from Glyricidia plants were plucked, weighed and washed prior to pulping as described by Fellows (1987) (fig. 1). The pulping helped to rupture the plant cell walls. The juice, which contains most of the proteins, was squeezed from the leaf residue by using a screw press. The separated leaf juice was heated in batches to $80-90^{\circ} \mathrm{C}$ for $10 \mathrm{~min}$. This procedure coagulated the leaf proteins from the whey. The protein coagulum was separated from the whey using a rubber hose to siphon the hot whey (Agbede and Aletor, 2004). The coagulate proteins were then separated from the whey by filtering through a muslin cloth and pressed with a screw press to remove the remaining whey. The leaf protein was then washed with water, repressed, sun-dried and milled.

The schematic step by step preparation of leaf protein concentrate is described as below:

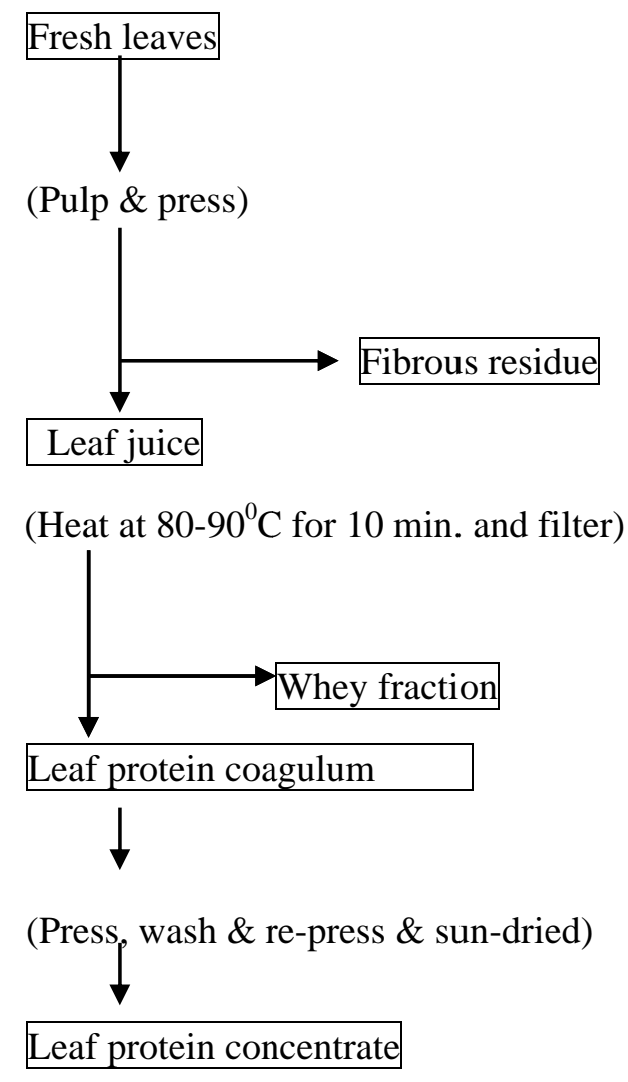

Figure 1. Leaf protein fractionation scheme: Fellows (1987)

Thereafter, the GLPC was used to formulate diets along with other ingredients purchased from Sunshine feed mill along Oka road, Ondo, Ondo State, Nigeria. GLPC was incorporated 


\section{Macrothink Institute ${ }^{\mathrm{TM}}$}

into five rabbit diets in which groundnut cake was replaced with GLPC at 0\% (control), 5, 10, 15 , and $20 \%$ in proportion of $1.31,2.62,3.93$ and $5.24 \%$, respectively for diets $2-5$ in the gross feed composition.

\section{Experimental Diets}

Five iso-nitrogenous and iso-caloric diets were formulated with the basal as well as the proximate composition as shown in Tables 1 and 2, respectively. Diet 1 was the control with $25 \%$ groundnut cake (GNC). The GNC protein was substituted at 5, 10, 15, and 20\% with GLPC in diets 2, 3, 4 and 5, respectively.

\section{Rabbits Management and Experimental Layout}

Thirty-five rabbits of mixed sexes aged 5-6 weeks were purchased for the feeding trial. Before the start of the experiment, the rabbits were made to undergo 7 days adaptation period during which they were offered commercial grower's mash feed (guinea feed) with $180 \mathrm{gkg}^{-1}$ crude protein and water provided ad-libitum. The reasons for the adaptation period was to enable the animals acclimatize to the facilities in the cage. Completely randomized design (CRD) was adopted for the trial. At the end of the acclimation period, the rabbits were individually weighed and randomly assigned to the five dietary treatment groups with seven rabbits to a treatment group and a rabbit taken as a replicate.

The experiment lasted for 56 days, during which the daily feed consumed and weekly weight changes taken.

\section{Data Collection}

\section{Performance Parameters}

\section{Feed Consumed $(g / d)$}

During the period of the experiment, data were collected on daily feed consumed Feed consumed was calculated as the difference between the feed given and the quantity of feed remaining plus the quantity of feed measured as waste.

\section{Average Weight Gain (g/d)}

Weekly weight gain was taken and calculated as the difference between the present weight and the weight for the preceding week.

\section{Carcass Characteristics and Organ Measurement}

At the end of the $8^{\text {th }}$ week, four rabbits chosen at random from each treatment group were starved overnight, stunned, sacrificed by cervical dislocation and dissected in accordance with the guidelines of the World Rabbit Science Association (WRSA). The dressed rabbits were later eviscerated. Twenty eviscerated carcasses at four per treatment were used for the measurement of the carcass characteristics viz: dressed carcass weight, eviscerated weight, thigh, shoulder, loin, ribs, neck, head, limbs and pelt. The organs were dissected out and blotted with filter paper. The organs measured were heart, lung, liver, kidney, pancreas and intestine. All the carcass characteristics and organs measured were expressed in \% body 
weight, except the dressed and eviscerated weights that were expressed in $\mathrm{gkg}^{-1}$ of the live weight.

\section{Haematology and Serum Determination}

Before slaughtering, Blood was collected from 5 rabbits chosen at random per treatment group from the marginal ear vein, using sterile lancets. Blood samples with ethylene diamine tetra acetic acid (EDTA) as anti-coagulant were used for the determination of the packed cell volume (PCV), red blood cell (RBC) counts, white blood cell (WBC) counts and haemoglobin concentration (Hb), while blood samples without anti-coagulant after decanting were used for the various serum biochemical constituents. The PCV were determined using the Wintrobe's microhematocrit technique while the RBC, WBC and $\mathrm{Hb}$ values were determined using the improved Neubauer hematocytometer and cyanomethae-moglobin method, respectively (Coles, 1986). The mean corpuscular hemoglobin concentration (MCHC) and mean corpuscular volume (MCV) were calculated (Jain, 1980). The serum glucose and blood urea were calculated (WHO, 1980), while the cholesterol, total serum protein, albumin and globulin concentration were by Biuret method Bush (1975).

\section{Chemical and Statistical Analyses}

The proximate composition of the experimental diets and test ingredient (Tables 2 and 3) were determined by the method of AOAC (1990). Data collected on carcass characteristics, organ weight, hematological components, and serum metabolites were subjected to one-way analysis of variance procedure using SPSS (2006) version 15 software. Where significant differences were observed, the means were compared using the Duncan option of the same statistical software package.

\section{Results}

The chemical composition as contained in Table 3 revealed the proximate chemical composition, mineral constituents, amino acid profile, anti-nutritional factors and gross energy of GLPC. The values showed that glyricidia leaf protein concentrate contained appreciable level of nutrients. The crude fibre $\left(8.3 \mathrm{~g} 100 \mathrm{~g}^{-1}\right)$ and ash $\left(7.5 \mathrm{~g} 100 \mathrm{~g}^{-1}\right)$ were higher than the conventional soybean and groundnut cake while the ether extract (fat) was lower $\left(14.32 \mathrm{~g}_{100 \mathrm{~g}^{-1}}\right)$ than those of soybean meal, groundnut cake and fish meal. Among the major minerals analyzed, Phosphorus (P) appeared to be the highest $\left(3441.3 \mathrm{mgkg}^{-1}\right)$ followed by Sodium (Na) (203.5 $\left.\mathrm{mgkg}^{-1}\right)$ while Potassium (K) had the least $\left(109.3 \mathrm{mgkg}^{-1}\right)$ values. Iron (Fe) had the highest $\left(102.5 \mathrm{mgkg}^{-1}\right)$ value while Manganese $(\mathrm{Mn})$ recorded the lowest $\left(4.2 \mathrm{mgkg}^{-1}\right)$ value among the minor minerals. This study showed that GLPC contained some nutritionally valuable mineral elements. The mineral contents observed in this study were lower than the conventional orthodox groundnut cake and soybean meal but within the recommendation for rabbit performance.

The amino acid profile of GLPC showed that it contained reasonable content of amino acid as revealed thus; lysine: 6.31 , methionine:2.17, arginine: 5.82, threonine: 5.16 , cystine: 2.68 , leucine:10.03, isoleucine:4.83, proline: 4.28 , tyrosine: 4.39 , alanine: 6.05 , phynalanine: 6.25 , valine: 5.92, histidine: 3.11, tryptophan: 1.72 glutamic acid: 10.79 glycine: 6.15 and aspartic 
acid: $10.02 \mathrm{mgkg}^{-1}$. The anti-nutrient contents showed the level of phytin, phytin-P, tannin and oxalate in GLPC. The GLPC contained $0.53 \mathrm{gkg}^{-1}$ phytin, $0.12 \mathrm{gkg}^{-1}$ phytin-P, $0.08 \mathrm{gkg}^{-1}$ oxalate and $0.17 \mathrm{gkg}^{-1}$ poly phenols as tannic equivalent. The lower contents of the anti-nutritional factors might be due to the fractionation process employed to extract the leaf protein concentrate.

\section{General Observation}

Throughout the period of the experiment all the rabbits were alert and showed no signs of physiological disorder.

\section{Characteristics and Relative Organ Weights}

Results on Table 4 showed that the final weight and the average weight gain g/rabbit/day were not significantly $(\mathrm{P}>0.05)$ influenced $(\mathrm{P}>0.05)$ by the various dietary treatments. Weight gain of rabbits fed the control diet were similar $(\mathrm{P}>0.05)$ to those fed the experimental diets up to $5.24 \%$ GLPC-based diet. Linearly, the average weight gain was least (10.27g/rabbit/day) at 5.24\% GLPC-based diet, but not significantly $(\mathrm{P}>0.05)$ different $(\mathrm{P}>0.05)$ from other experimental diets.

Dressed carcass weight, eviscerated weight, thigh, loin and head weights were not significantly $(\mathrm{P}>0.05)$ influenced $(\mathrm{P}>0.05)$ by the dietary treatments. Other parameters measured showed significant $(\mathrm{P}<0.05)$ differences $(\mathrm{P}<0.05)$ between the various test diets and the control diet. The shoulder and ribs weights of rabbits fed the control diet were similar $(\mathrm{P}>0.05)$ to the rabbits fed 1.31, 2.62 and 5.24\% GLPC-based diets but significantly $(\mathrm{P}<0.05)$ lower $(\mathrm{P}<0.05)$ than those rabbits placed on 3.93\% GLPC-based diet (diet 4 ), being the one with the highest shoulder and ribs weight (10.54 and $4.51 \%$ body weight, respectively). The neck weight showed no significant $(\mathrm{P}>0.05)$ difference $(\mathrm{P}>0.05)$ between the control diet and rabbits fed 1.31 and 3.93\% GLPC-based diets, but significantly $(\mathrm{P}<0.05)$ different $(\mathrm{P}<0.05)$ from rabbits placed on 2.62 and 5.24\% GLPC-based diet. On the limbs weight, there were no significant $(\mathrm{P}>0.05)$ differences $(\mathrm{P}>0.05)$ between rabbits on the control diet and diets 3,4 or 5 , but diet $2(1.31 \%$ GLPC-based diet) significantly $(\mathrm{P}<0.05)$ promoted $(\mathrm{P}<0.05)$ the limbs weight above those on diets 1 and 3 . Only diets 3 and 4 showed significant $(\mathrm{P}<0.05)$ difference $(\mathrm{P}<0.05)$ in rabbits pelt weight, other test diets promoted similar $(\mathrm{P}>0.05)$ pelt weight. On the carcass length, only diet 4 (3.93\% GLPC-based diet) and diet 5 (5.24\% GLPC-based diet) showed significant $(\mathrm{P}<0.05)$ difference $(\mathrm{P}<0.05)$ on the carcass length, other test diets promoted similar $(\mathrm{P}>0.05)$ carcass length of the experimental rabbits.

Table 5 showed that of all the relative organ weights measured, only the liver and pancreas were not significantly $(\mathrm{P}>0.05)$ influenced $(\mathrm{P}>0.05)$ by the test diets. Heart, liver and kidney weights were significantly $(\mathrm{P}<0.05)$ higher $(\mathrm{P}<0.05)$ at $3.93 \%$ GLPC-based diet and above. Lung weights was highest (0.89 \%body weight) at 1.31\% GLPC-based diet, though not significantly $(\mathrm{P}>0.05)$ different $(\mathrm{P}>0.05)$ from rabbits fed 3.93\% GLPC-based diet, but significantly lower $(\mathrm{P}<0.05)$ than the control diet, being the one with the lowest $(0.63$ \%body weight) lung weight. 


\section{Hematological Profile and Serum Biochemical Indices}

Table 6 showed the hematological indices of rabbits fed GLPC-based diets compared to groundnut cake-based diet (reference diet). Results revealed no significant $(\mathrm{P}>0.05)$ difference in the PCV (37.52-38.98\% vs 39.43\%), RBC (6.99-7.21 $10^{9} / \mathrm{ml}$ vs $\left.6.8010^{9} / \mathrm{ml}\right)$, MCH (20.12-21.19pg vs 21.65pg), MCHC (30.48-31.31\% vs 31.73\%) and $\mathrm{Hb}$ (11.53-11.91g/dL vs $12.11 \mathrm{~g} / \mathrm{dL})$. However, the WBC and MCV were significantly $(\mathrm{P}<0.05)$ lower with values $5.3210 \% \mathrm{ml}$ and $55.27 \mathrm{fl}$, respectively compared to other test diets with range values 6.03-7.63 $10^{9} / \mathrm{ml}$ and 61.82-63.05fl for WBC and MCV, respectively. The serum metabolites (Table 7) showed lower significant $(\mathrm{P}<0.05)$ value at $15 \%$ and above GLPC-based diet for serum protein compared to other test diets which were not significant $(\mathrm{P}>0.05)$, and at $10 \%$ and above GLPC-based diets $(9.40-10.22 \mathrm{~mol} / \mathrm{L})$ as against $11.02-11.13 \mathrm{~mol} / \mathrm{L}$ for rabbits fed $0-5 \%$ GLPC-based diets. Other serum metabolites determined such as albumin, globulin, albumin/globulin ratio, blood urea and cholesterol showed no significant $(\mathrm{P}>0.05)$ difference among all rabbits fed the test diets.

\section{Discussion}

Data on the proximate composition, mineral constituents, amino acid profile, anti-nutritional constituents and gross energy of GLPC fell within the range of nutrients earlier reported by Agbede and Aletor (2004) and Agbede (2006). Its energy content was however lower $\left(22.30 \mathrm{MJkg}^{-1}\right)$ than that of Centrosema pubesens leaf protein concentrate $\left(22.80 \mathrm{MJkg}^{-1}\right)$ (Agbede, 2006) and the conventional soybean meal and groundnut cake, but higher than the value $\left(21.8 \mathrm{MJkg}^{-1}\right)$ obtained by Agbede (2006) for glyricidia leaf protein concentrate. The increase in the gross energy value might be due to the process of fat extraction from the ingredient. The crude fibre and ash were higher than those of soybean meal and groundnut cake (Agbede and Aletor, 2004; Fasuyi, 2005) while the ether extract was lower than those of soybean meal, groundnut cake and fish meal (Agbede and Aletor, 2004). The mineral contents also fell within those reported by Agbede and Aletor (2004), Agbede (2006) for GLPC and Aletor et al. (2002) for leafy vegetable protein concentrates. The amino acid constituents fell within the range recommended for rabbits in the tropics (NRC, 1984) and the low anti-nutritional levels might be due to the fractionation process employed to extract the leaf protein concentrate (Oke, 1973; Agbede and Aletor, 2004). The non-significant ( $\mathrm{P}>0.05)$ difference $(\mathrm{P}>0.05)$ in the average weight gain showed that the various dietary treatments promoted similar growth in the experimental rabbits. The reason for this could be due to the similar nutrient density in the experimental diets. The non-significant $(\mathrm{P}>0.05)$ difference ( $\mathrm{P}>0.05)$ observed agrees with the reports by Omole (1982) and Aduku et al. (1988) on browse legumes fed to rabbits, and Ahn (1990) that the use of up to $20 \%$ glyricidia leaf meal in rabbit diets does not adversely reduce tissue synthesis. Also, Babayemi (2009) reported that up to $10 \%$ level of Centrosema leaf protein showed no any adverse effect on weight gain of weaned rabbits of similar weight. The dressed carcass weight and eviscerated weight observed in this study is in line with the reports by Omer et al. (2010) that showed no significant difference in rabbits fed lemon grass and active dried yeast, although I. E. S. R (2003) reported higher carcass weight of rabbits fed lemon grass or active dried yeast mixed 
with concentrates. The carcasses such as thigh, loin and head weights that were unaffected by variation in dietary GLPC, indicate that rabbits can tolerate up to 20\% i.e. 5.24\% GLPC on equi-protein basis with GNC in their diet. This result corroborates the work by Amata (2010) that up to $20 \%$ glyricidia leaf meal in place of groundnut cake had no deleterious effects on the rabbit's carcass cuts. Jumoke et al. (2006) reported similar carcass traits in broilers fed bread fruit meal substituted for groundnut cake in broiler diet. Organs such as heart, kidney and intestine were not significantly influenced $(\mathrm{P}>0.05)$ by the dietary treatments, except rabbits fed 3.93\% GLPC-based diet. This result supported the report by Hellwing et al. (2007) and Njidda and Isidahomen (2011) that bacterial protein meal supplementation and sesame seed meal, respectively in rabbit diet did not affect the organ growth of rabbits. The implication therefore is that GLPC does not contain high toxic substance that can cause hypertrophy of organs which is usually due to overworking of the organs in an attempt to eliminate toxic feed components.

Hematological values are indirect indices to the health status of livestock (Kecceci et al., 1998). The values reported for the various blood parameters showed the rabbits were in good health condition. This is also evidenced in the $0 \%$ mortality recordled throughout the experimental period. The low level of WBC could be due the residual effect of anti-nutrient at higher GLPC inclusion level (Mahajan and Agrawal, 1980). Researchers such as Madubuike and Ekeyem (2006), Talebi et al. (2009) and Emenalom et al. (2009) had at one time or the other reported that diets could have a modifying effect on the haematology of animals. Decrease in serum protein and blood glucose at higher GLPC inclusion could be due to dietary influence, as blood protein is usually affected by plain nutrition (NRC, 1984). The values reported for albumin, globulin and albumin/globulin ratio were within the normal range for healthy rabbit (RAR, 2007), and values obtained for the blood urea and cholesterol could be due to the fat content in the formulated diets (Table 2).

\section{Conclusion}

The study showed that GLPC contained appreciable quantity of minerals and reasonable levels of amino acid with lower contents of anti-nutrients that are tolerable by rabbits. Dietary treatment had no negative influence up to 5.24\% GLPC-based diet on the carcass characteristics, organ weights, hematological profile and serum characteristics of weaned rabbits, and as such glyricidia leaf protein concentrate could be substituted for groundnut cake up to $20 \%$ inclusion level as protein source in rabbit's concentrate diet.

\section{Recommendation}

Based on the findings of this study, dietary inclusion of glyricidia leaf protein up to $5.24 \%$ in place of groundnut cake had no dire consequence on the carcass cuts, organ weights, hematological indices and serum constituents of weaned rabbits. It can therefore be said that rabbits in the tropics can be raised on up to 5.24\% GLPC-based diet without any deleterious effect on them. Rabbit farmers in the tropical region where glyricidia browse plants abound are encouraged to incorporate GLPC up to $20 \%$ optimal inclusion level in rabbit's concentrate diet as source of dietary protein in place of groundnut cake as. 


\section{References}

Adeyemi, O.A., Ajade, A.O., Okubanjo, A.O., \& Eniolorunda, O.O. (2010). Response of Growing Rabbits to Graded levels of Fermented. Electronic Journal of Environment, Agriculture and Food Chemistry, 9(5), 898-909.

Aduku, A.O., Okon, P.N., Njoku, P.C., Akanga, A.A., \& Dim, M.I. (1988). Evaluation of cowpea (Vigna unguiculata) and peanut (Arachis hypogea) haulms as feedstuffs for weaned rabbits in tropical environment (Nigeria). Journal of Applied Rabbit Research, 9, 178-180.

Agbede, J.O. (2000). Characterization of the leaf meals, protein concentrates and residues from some tropical leguminous plants. Journal of Science, Food and Agriculture, 86, 1292-1297. http://dx.doi.org/10.1002/jsfa.2491

Agbede, J.O. (2003). Equi-protein Replacement of fish meal with Leucaena leaf protein concentrate: An Assessment of performance characteristics and Muscle Development in the chicken. International Journal of Poultry Science, 2(6), 421-429. http://dx.doi.org/10.3923/ijps.2003.421.429

Agbede, J.O., \& Agbede, A.B. (2009). Leaf protein concentrates: Panacea for relieving protein under-nutrition in Nigeria. Proceedings of Humboldt Kellog/5 ${ }^{\text {th }}$ SAAT Annual Conference, Federal University of Technology, Akure, Nigeria. $21^{\text {st }}$ April, 2009.

Agbede, J.O., \& Aletor, V.A. (2004). Chemical characterization and protein quality evaluation of leaf protein concentrates from Glyricidia sepium and Leucaena leucocephala. International Journal of Food Science and Technology, 39, 253-261. http://dx.doi.org/10.1111/j.1365-2621.2004.00779.x

Agbede, J.O., \& Aletor, V.A. (2005). Studies of the chemical composition and protein quality evaluation of differently processed Canavalia ensiformis and Mucuna pruriens see flours. Journal of Food Composition and Analysis, 18, 89-103. http://dx.doi.org/10.1016/j.jfca.2003.10.011

Agbede, J.O., Adegbenro, M., Onibi, G.E., Oboh, C., \& Aletor, V.A. (2008). Nutritive evaluation of Telfaria occidentalis leaf protein concentrate in infant foods. African Journal of Biotechnology, 7(5), 2721-2727.

Ahn, J.N. (1990). Quality assessment of tropical browse legume: Tannin content and nitrogen degradability. Ph.D Thesis, University of Queensland, Australia. 156pp.

Aletor, O., Oshodi, A., \& Ipinmoroti, K.O. (2002). Chemical composition of Lemon leafy vegetables and functional properties of their leaf protein concentrate. Food Chemistry, 78, 63-68. http://dx.doi.org/10.1016/S0308-8146(01)00376-4

Aletor, V.A., \& Omodara, O.A. (1994). Studies on some leguminous browse plants with particular reference to their proximate, mineral and some endogenous anti-nutrient constituents Animal Feed Science Technology, 4, 343-348. http://dx.doi.org/10.1016/0377-8401(94)90151-1 
Amata, I.A. (2010). The effect of feeding Glyricidia leaf meat (GLM) on the hematological, serological and carcass characteristics of weaned rabbits in the tropics. Agriculture and Biology Journal of North America, 1(5), 1057-1060. http://dx.doi.org/10.5251/abjna.2010.1.5.1057.1060

Amata, I.A., \& Bratte, L. (2008). The Effect of Partial Replacement of Soybean meal with Glyricidia leaf meal on the Performance and Organ weights of weaner Rabbits in the Tropics. Asian Journal of Animal and Veterinary Advances, 3(3), 169-173. http://dx.doi.org/10.3923/ajava.2008.169.173

AOAC, (1990). Association of Official Analytical Chemist. Official method of analysis $11^{\text {th }}$ (ed.) Washington D.C.

Babayemi, O.J. (2009). Supplementary value of Tephrosia bacteolata, Tephrosia candida, Leucaena leucocephala and Glyricidia sepium hay for West African Dwarf Goats. Trop. Sub-trop. Agro-ecosystem, 6(1), 15-27.

Bush, B.M. (1975). Veterinary Laboratory Manual. William Heineman Medical Books Ltd., London, UK.

Coles, E.H. (1986). Veterinary Clinical Pathology. 4th Ed., W. B. Saunders, Philadephia, USA

Emenalom, O.O., Esonu, B.O., Etuk, E.B., \& Amaba, C. (2009). Effect of Mucuna pruriens (Velvet bean) leaf meal on performance and blood composition of finisher broiler chicks. Nigerian Journal of Animal Production, 36, 52-60

Fasuyi, A.O. (2005). Nutritional evaluation of cassava (Manihot esculenta, crantz) leaf protein concentrates (CLPC) as alternative protein sources in rat assay. Pakistan Journal of Nutrition, 4(1), 50-56. http://dx.doi.org/10.3923/pjn.2005.50.56

Fellows, P. (1987). Village-scale leaf fractionation in Ghana. Tropical Science, 27, 77-84.

Ghosh, N., \& Mandal, L. (2008). Carcass and meat quality traits of rabbits (Oryctolagus cuniculus) under warm-humid condition of West Bengal, India. Livestock Research for Rural Development, 20(9), 1-7. www.lrrd.org/lrrd20/9/ghos20146.html

Hellwing, A.L.F., Tauson, A.H., Kjos, N.P., \& Skrede, A. (2007). Bacterial protein meal in diets for growing pigs: effects on protein and energy metabolism. Animal Science Journal, 1, 45-54.

I E S R. (2003). Institute of Environmental Studies and Research: Use of black cumin and lemon grass processing waste in rabbits feeding. Journal of Environmental Science, Anim Shams University, 6(1).

Jain, N.C. (1986). Schalm Veterinary Haematology. 4th edition, Lea and Febiger, Philadephia. Jumoke, A., Amos, O., Fanimo, L.A., Bamgbose, A.D., \& Olayinka, O. (2006). Nutrient utilization, growth and carcass performance of broiler chickens fed graded levels of bread fruit meal. Journal of Poultry Science, 43, 365-370. http://dx.doi.org/10.2141/jpsa.43.365 
Kecceci, T., Oguz, H., Kurtoglu, V., \& Demet, O. (1998). Effect of Polyvinylpyrrodine, synthetic zeolite and bentonite on serum biochemical and haematological character of broiler chickens during aflatoxicosis. British Poultry Science, 39, 152-158. http://dx.doi.org/10.1080/00071669889051

Madubuike, F. N., \& Ekeyem, B.U. (2006). Hematology and serum biochemistry characteristics of broiler chicks fed varying dietary levels of Ipomea asarifolia leaf meal. International Journal of Poultry Science, 5, 9-12. http://dx.doi.org/10.3923/ijps.2006.9.12

Mahajan, C.L., \& Agrawal, N.K. (1980). Hematological changes due to vitamin C deficiency in Ghana Punctatus. Journal of Nutrition, 110, 2171-2182

National Research Council. (1984). Nutrient requirement of rabbits, $2^{\text {nd }}$ edition revised. National Academy of Sciences, Washington DC, USA

Njidda, A.A., \& Hambagda, A.A. (2007). Performance characteristics and nutrient digestibility of weaning rabbits fed graded levels of sesame meal (Sesame indicum) in semi-arid region of Nigeria. Journal of Agricultural Research and Policy, 2(1), 208-212

Njidda, A.A., \& Isidahomen, C.E. (2011). Hematological parameters and carcass characteristics of weaning rabbits fed sesame seeds meal (Sesamum indicum) in a semi-arid region. Pakistan Veterinary Journal, 31(1), 35-39

Ogunsipe, M.H., Akinbani, A.S., \& Ibidapo, I. (2011). Performance evaluation and economics of production of rabbits fed graded levels of glyricidia leaf protein concentrate as replacement for ground nut cake protein. International Journal of Agricultural Science, Research and Technology, 1(2), 67-72.

Oke, O.L. (1973). Leaf protein research in Nigeria. A review. Tropical Science, 15, 139-155.

Okonkwo, J.C., Okonkwo, I.F., \& Umerie, S.C. (2010). Replacement of Feed concentrate with Graded levels of cassava leaf meal of the Diet of Growing Rabbits: Effect on feed and Growth Parameters. Pakistan Journal of Nutrition, 9(2), 116-119. http://dx.doi.org/10.3923/pjn.2010.116.119

Omer, H.A.A., Hewida, M.H., Elallawy Laida, D., \& AbdEl-Samee, Nagwa Maghraby. (2010). Productive performance of rabbits fed diets containing lemon grass or active dried yeast. American-Eurasian Journal of Agriculture, Environment and Science, 7(2), 179-187

Omole, T. A. (1982). The effect of different levels of dietary protein on growth and reproductive performance of rabbits. Journal of Applied Rabbit Research, 5, 83-88.

RAR, (2007). Reference values for laboratory animals: Normal Hematological Values. Research Animal Resources, University of Minnesota. http;//www.ahc.umn.edu/rar/index.html.

SPSS (2006). Statistical Package for Social Scientists. S.P.S.S Base 15.0 User's Guide, Copyright (C2006. S.P.S.S. Inc., 233 South Wacker Drive, 11th Floor, Chicago, IL 60606-6412. 
Talebi, A., Asri-Rezaei, S., Rozeh-Chai, R., \& Sahraei, R. (2005). Comparative studies on haematology values of broiler strains (Ross, Cobb, Arbor, Acres and Arian). International Journal of Poultry Science, 4, 573-579. http://dx.doi.org/10.3923/ijps.2005.573.579

WHO. (1980). Manual of Basic Technique for a Health Laboratory. World Health Organization, Geneva, Switzerland

Table 1. Composition of experimental diets (g/100g) for growing rabbits

Ingredients Levels of Glyricidia Leaf Protein Concentrate (\%)

$\begin{array}{lllll}0 & 5 & 10 & 15 & 20\end{array}$

Diets

\begin{tabular}{llllll} 
& 1 & 2 & 3 & 4 & 5 \\
\hline Maize & 54.85 & 54.20 & 53.55 & 52.90 & 52.25 \\
GNC & 25.00 & 23.75 & 22.50 & 21.25 & 20.00 \\
GLPC & - & 1.31 & 2.62 & 3.93 & 5.24 \\
Wheat offal & 5.00 & 5.04 & 5.08 & 5.12 & 5.16 \\
Rice bran & 10.00 & 10.55 & 11.10 & 11.65 & 12.20 \\
Bone meal & 2.50 & 2.50 & 2.50 & 2.50 & 2.50 \\
Blood meal & 2.00 & 2.00 & 2.00 & 2.00 & 2.00 \\
Salt & 0.20 & 0.20 & 0.20 & 0.20 & 0.20 \\
Premix & 0.25 & 0.25 & 0.25 & 0.25 & 0.25 \\
Lysine & 0.10 & 0.10 & 0.10 & 0.10 & 0.10 \\
Methionine & 0.10 & 0.10 & 0.10 & 0.10 & 0.10 \\
Total & 100 & 100 & 100 & 100 & 100 \\
\end{tabular}

Table 2. Proximate composition (g/100g) and energy content (GE/Kcalg $\left.{ }^{-1}\right)$ of experimental diets

\begin{tabular}{lllllllll}
\hline Diets & \% GNC replaced with GLPC & DM & CP & Ash & Fat & CF & NFE & GE \\
\hline 1 & 0 & 91.08 & 18.59 & 4.33 & 5.06 & 10.13 & 61.89 & 2.66 \\
2 & 5 & 90.58 & 18.61 & 4.18 & 4.64 & 10.39 & 62.18 & 2.70 \\
3 & 10 & 90.19 & 18.69 & 3.96 & 4.81 & 10.85 & 61.69 & 2.65 \\
4 & 15 & 89.93 & 18.54 & 4.11 & 4.51 & 11.58 & 61.26 & 2.68 \\
5 & 20 & 90.10 & 18.81 & 4.30 & 4.71 & 12.33 & 59.85 & 2.63 \\
SEM & & 0.37 & 0.07 & 0.11 & 0.17 & 0.811 & 0.84 & 0.02 \\
Sig. & & NS & NS & NS & NS & NS & NS & NS \\
\hline
\end{tabular}




\section{Macrothink}

Journal of Food Studies

ISSN 2166-1073

2013, Vol. 2, No. 1

Table 3. Proximate composition (g/100g), Gross Energy $\left(\mathrm{MJkg}^{-1}\right)$, Mineral constituents $\left(\mathrm{mgkg}^{-1}\right)$, Amino acid composition (\%) and Anti-nutritional contents $\left(\mathrm{gkg}^{-1}\right)$ of GLPC

\begin{tabular}{|c|c|c|c|c|c|c|c|c|c|c|}
\hline Proximate & \multirow{2}{*}{\multicolumn{2}{|c|}{$\begin{array}{l}\text { DM } \\
90.50\end{array}$}} & $\mathrm{CP}$ & \multirow{2}{*}{\multicolumn{2}{|c|}{$\begin{array}{l}\text { CF } \\
8.30\end{array}$}} & $\mathrm{EE}$ & Ash & \multicolumn{2}{|l|}{ NFE } & \multirow[t]{2}{*}{ GE } \\
\hline \multirow[t]{2}{*}{ composition } & & & & & & & & & & \\
\hline & & & 42.03 & & & 14.32 & 7.50 & 27.85 & & 22.30 \\
\hline \multirow{3}{*}{$\begin{array}{l}\text { Mineral } \\
\text { constituents }\end{array}$} & \multicolumn{2}{|c|}{ Macro } & & & & & Micro & & & \\
\hline & $\mathrm{Ca}$ & $\mathrm{P}$ & $\mathrm{Na}$ & K & $\mathrm{Mg}$ & $\mathrm{Fe}$ & $\mathrm{Cu}$ & $\mathrm{Mn}$ & $\mathrm{Zn}$ & \\
\hline & 171.3 & 3441.3 & 203.5 & 109.3 & 173.9 & 102.5 & 18.9 & 4.2 & 32.7 & \\
\hline \multirow[t]{6}{*}{ Amino Acid profile } & \multicolumn{10}{|c|}{ essential/indispensable amino acid } \\
\hline & Arg. & Hist. & Leu. & Lys. & Meth. & Isoleu. & Trypto. & Phenyala.. & Threo & Val. \\
\hline & 5.82 & 3.11 & 10.03 & 6.31 & 2.17 & 4.83 & 1.72 & 6.25 & 5.16 & 5.02 \\
\hline & \multicolumn{10}{|c|}{ non-essential/dispensable amino acid } \\
\hline & & Cyst. & Gly. & Tyro. & Ala. & Pro. & Glu. & Asp. & & \\
\hline & & 2.68 & 6.15 & 4.39 & 6.05 & 4.28 & 10.79 & 10.02 & & \\
\hline Anti-nutritional & & Phytin & & Phytin-P & & Oxalate & & Tannin & & \\
\hline components & & 0.53 & & 0.12 & & 0.08 & & 0.17 & & \\
\hline
\end{tabular}

Table 4. Carcass traits (\% body weight) of rabbits fed GLPC-based diets

\begin{tabular}{llllllll}
\hline & Diet 1 & Diet 2 & Diet 3 & Diet 4 & Diet 5 & SEM & Sig. \\
Parameters & 0 & 5 & 10 & 15 & 20 & & \\
\hline Initial weight g & 470.00 & 512.50 & 479.70 & 470.60 & 500.70 & 17.34 & NS \\
Final weight g & 1084.50 & 1212.50 & 1167.20 & 1180.10 & 1075.20 & 49.93 & NS \\
Slaughter weight g & 1049.50 & 1162.50 & 1112.20 & 1053.70 & 1021.80 & 46.09 & NS \\
Average weight gain/rabbit/g/d & 10.94 & 12.50 & 12.28 & 11.38 & 10.27 & 0.76 & NS \\
& & & & & & & \\
Dressed carcass weight (\%) & 408.83 & 487.50 & 450.75 & 454.75 & 431.75 & 19.83 & NS \\
Eviscerated weight (\%) & 270.00 & 287.05 & 328.00 & 324.55 & 266.50 & 21.16 & NS \\
Pelt & $6.82^{\mathrm{ab}}$ & $7.22^{\mathrm{ab}}$ & $9.25^{\mathrm{b}}$ & $6.62^{\mathrm{a}}$ & $7.22^{\mathrm{ab}}$ & 0.89 & $*$ \\
Thigh & 15.19 & 16.57 & 15.29 & 16.74 & 16.30 & 0.47 & NS \\
Shoulder & $8.45^{\mathrm{a}}$ & $8.46^{\mathrm{a}}$ & $8.82^{\mathrm{ab}}$ & $10.54^{\mathrm{b}}$ & $9.40^{\mathrm{ab}}$ & 0.77 & $*$ \\
Loin & $8.34^{\mathrm{a}}$ & $8.46^{\mathrm{a}}$ & $8.85^{\mathrm{ab}}$ & $10.54^{\mathrm{b}}$ & $9.56^{\mathrm{ab}}$ & 0.74 & $*$ \\
Ribs & $3.50^{\mathrm{a}}$ & $3.29^{\mathrm{a}}$ & $3.28^{\mathrm{a}}$ & $4.51^{\mathrm{b}}$ & $3.52^{\mathrm{a}}$ & 0.36 & $*$ \\
Neck & $0.99^{\mathrm{a}}$ & $0.87^{\mathrm{a}}$ & $1.24^{\mathrm{b}}$ & $0.93^{\mathrm{a}}$ & $1.31^{\mathrm{b}}$ & 0.15 & $*$ \\
Head & 8.62 & 8.63 & 8.52 & 8.79 & 8.74 & 0.23 & NS \\
Limbs & $3.09^{\mathrm{a}}$ & $3.77^{\mathrm{b}}$ & $2.83^{\mathrm{a}}$ & $3.42^{\mathrm{ab}}$ & $3.55^{\mathrm{ab}}$ & 0.36 & $*$ \\
Carcass length (cm) & $28.60^{\mathrm{ab}}$ & $28.40^{\mathrm{ab}}$ & $29.20^{\mathrm{ab}}$ & $27.80^{\mathrm{a}}$ & $29.80^{\mathrm{b}}$ & 1.27 & $*$ \\
\hline
\end{tabular}

${ }^{\mathrm{ab}}$ means in the same row with different superscripts are significant $(\mathrm{P}<0.05)$ 
Table 5. Relative organ weights (\% body weight) of rabbits fed GLPC-based diets

\begin{tabular}{|c|c|c|c|c|c|c|c|}
\hline & Diet 1 & Diet 2 & Diet 3 & Diet 4 & Diet 5 & SEM & Sig \\
\hline \multicolumn{8}{|c|}{ Levels of Glyricidia leaf protein concentrate (\%) } \\
\hline Parameters & 0 & 5 & 10 & 15 & 20 & & \\
\hline Heart & $0.23^{\mathrm{a}}$ & $0.20^{\mathrm{a}}$ & $0.21^{\mathrm{a}}$ & $0.27^{\mathrm{b}}$ & $0.27^{\mathrm{b}}$ & 0.02 & $*$ \\
\hline Lung & $0.63^{\mathrm{a}}$ & $0.89^{\mathrm{c}}$ & $0.72^{\mathrm{b}}$ & $0.84^{\mathrm{bc}}$ & $0.79^{\mathrm{ab}}$ & 0.07 & $*$ \\
\hline Liver & $2.14^{\mathrm{a}}$ & $2.16^{\mathrm{a}}$ & $2.43^{\mathrm{ab}}$ & $2.65^{\mathrm{b}}$ & $3.10^{\mathrm{b}}$ & 0.38 & * \\
\hline Kidney & $0.57^{\mathrm{a}}$ & $0.50^{\mathrm{a}}$ & $0.54^{\mathrm{a}}$ & $0.65^{\mathrm{b}}$ & $0.62^{\mathrm{b}}$ & 0.04 & $*$ \\
\hline Pancreas & 0.09 & 0.08 & 0.09 & 0.10 & 0.09 & 0.01 & NS \\
\hline Intestine + content & $19.20^{\mathrm{a}}$ & $19.38^{\mathrm{a}}$ & $18.53^{\mathrm{a}}$ & $24.96^{\mathrm{b}}$ & $20.21^{\mathrm{a}}$ & 2.32 & $*$ \\
\hline
\end{tabular}

${ }^{\mathrm{abc}}$ means in the same row with different superscripts are significant $(\mathrm{P}<0.05)$

Table 6. Haematological parameters of weaned rabbits fed GLPC-based diets

$\begin{array}{lllllll}\text { Diet } 1 & \text { Diet } 2 & \text { Diet } 3 & \text { Diet } 4 & \text { Diet } 5 & \text { SEM } & \text { Sig. }\end{array}$

Levels of Glyricidia leaf protein concentrate (\%)

\begin{tabular}{llllllll} 
Parameters & 0 & 5 & 10 & 15 & 20 & & \\
\hline PCV $(\%)$ & 39.43 & 38.97 & 37.28 & 37.81 & 37.52 & 0.73 & NS \\
RBC $\left(10^{9} / \mathrm{ml}\right)$ & 6.80 & 7.21 & 6.99 & 7.13 & 7.08 & 0.08 & NS \\
WBC $\left(10^{9} / \mathrm{ml}\right)$ & $7.63^{\mathrm{a}}$ & $7.39^{\mathrm{a}}$ & $6.65^{\mathrm{a}}$ & $6.03^{\mathrm{ab}}$ & $5.32^{\mathrm{b}}$ & 0.62 & $*$ \\
MCH (pg) & 21.65 & 21.19 & 20.93 & 20.79 & 20.12 & 0.35 & NS \\
MCHC (\%) & 31.73 & 30.48 & 31.31 & 31.03 & 30.62 & 0.39 & NS \\
MCV (fl) & $63.05^{\mathrm{a}}$ & $61.52^{\mathrm{a}}$ & $61.82^{\mathrm{a}}$ & $62.34^{\mathrm{a}}$ & $55.27^{\mathrm{b}}$ & 0.71 & $*$ \\
Hb (g/dL) & 12.11 & 11.73 & 11.82 & 11.53 & 11.91 & 0.14 & NS \\
\hline
\end{tabular}

${ }^{\mathrm{ab}}$ means in the same row with different superscripts are significant $(\mathrm{P}<0.05)$

Table 7. Serum biochemical of weaned rabbits fed GLPC-based diets

$\begin{array}{lllllll}\text { Diet } 1 & \text { Diet } 2 & \text { Diet } 3 & \text { Diet } 4 & \text { Diet } 5 & \text { SEM } & \text { Sig. }\end{array}$

Levels of Glyricidia leaf protein concentrate (\%)

\begin{tabular}{|c|c|c|c|c|c|c|c|}
\hline Parameters & 0 & 5 & 10 & 15 & 20 & & \\
\hline Albumin (g/dL) & 3.02 & 2.86 & 2.67 & 2.71 & 2.63 & 0.11 & NS \\
\hline Globulin (g/dL) & 1.98 & 1.93 & 1.84 & 1.81 & 1.91 & 0.04 & NS \\
\hline $\begin{array}{l}\text { Albumin/globulin } \\
\text { ratio }\end{array}$ & 1.51 & 1.48 & 1.44 & 1.49 & 1.38 & 0.03 & NS \\
\hline $\begin{array}{ll}\text { Serum } & \text { prote } \\
(\mathrm{g} / \mathrm{dL}) & \end{array}$ & $8.17^{\mathrm{a}}$ & $8.01^{\mathrm{a}}$ & $7.85^{\mathrm{a}}$ & $7.46^{\mathrm{a}}$ & $7.21^{b}$ & 0.27 & $*$ \\
\hline $\begin{array}{l}\text { Blood } \\
(\mathrm{mol} / \mathrm{L})\end{array}$ & $11.13^{\mathrm{a}}$ & $11.02^{\mathrm{a}}$ & $10.22^{b}$ & $9.59^{c}$ & $9.40^{\mathrm{C}}$ & 0.62 & $*$ \\
\hline Blood urea (mol/L) & 10.57 & 10.71 & 10.77 & 10.61 & 10.68 & 0.21 & NS \\
\hline Cholesterol (mol/L) & 4.09 & 3.87 & 3.92 & 4.01 & 4.11 & 0.07 & NS \\
\hline
\end{tabular}

\footnotetext{
${ }^{\mathrm{abc}}$ means in the same row with different superscripts are significant $(\mathrm{P}<0.05)$
} 